Merima Činjarević*

UDK 339.138:336.71>(497.6)

Kasim Tatić**

Review

Armin Avdić ${ }^{* * *}$

Pregledni rad

\title{
AN INTEGRATED MODEL OF PRICE, SERVICE QUALITY, SATISFACTION AND LOYALTY: AN EMPIRICAL RESEARCH IN THE BANKING SECTOR OF BOSNIA AND HERZEGOVINA
}

\begin{abstract}
The relationship between service quality, price, customer satisfaction and customer loyalty is the subject of interests of researchers for several decades. Despite many publications on perceived quality, the position of the construct relative to the other key constructs in marketing remains vague. This research tries to bring conceptual clarity with regard to the relationship between perceived service quality, perceived price, customer satisfaction and customer loyalty. The proposed model is defined in line with the existing theoretical findings. Besides, this research is conducted to examine the sustainability of service quality dimensions and service price dimensions in Bosnia and Herzegovina's retail banking. In order to test the defined model and research hypotheses empirical research was conducted on the sample of 300 retail bank customers of three leading banks in Bosnia and Herzegovina. Research results indicate that the defined model has an acceptable level of fit to the empirical data. This paper contributes to the existing literature by identifying the effects of different service quality and price quality dimensions on customer satisfaction and loyalty. A dimensionspecific approach used in this study can help bank managers to gain useful insight regarding the relative contribution of each dimension to the management of customer satisfaction and loyalty. This research has several limitations that need to highlight. The sample size was relatively small $(n=300)$ and the survey was conducted in a single service setting with a few banks under investigation. Thus, future research with a larger sample and tested in other service setting is needed to enhance the generalizability of the findings.
\end{abstract}

Keywords: Service quality, Price, Customer satisfaction, Customer loyalty, Retail banking

JEL Classification: M31, L80

\section{INTRODUCTION}

Service quality, as well as customer satisfaction and loyalty, are terms increasingly used in recent years. This relates to both, business and academic community. Bosnia and Herzegovina has also been enveloped by this trend, especially when it comes to the service sector. An intensive competition in the service market has surely contributed to emergence of a service quality to the forefront of everybody's interest. Irrespective of which business strategy a company opts for - either by resorting to standardization and centralization to cut

\footnotetext{
* Teaching Assistant, School of Economics and Business in Sarajevo, Bosnia and Herzegovina, merima.cinjarevic@efsa.unsa.ba

** Associate Professor, School of Economics and Business in Sarajevo, Bosnia and Herzegovina, kasim.tatic@efsa.unsa.ba

${ }^{* * *}$ Senior Teaching Assistant, School of Economics and Business in Sarajevo, Bosnia and Herzegovina, armin.avdic@efsa.unsa.ba
} 
back on costs and thus offer lower prices or by attempting to oppose the competition by providing exclusive services, the focus of both must be placed upon quality of services they provide. Provision of high quality service aids in meeting several requirements such as customer satisfaction and its consequent loyalty and market share, soliciting new customers and improved productivity, financial performance and profitability (Cui et al., 2003).

A review of literature indicates that studies related to service quality have been mainly conducted in US and developed European banking industries. Research on service quality in banking sector of South Eastern European countries is rather limited. This appears to be particularly the case within the Western Balkan countries. Therefore, it is desirable to conduct the study on service quality in the context of banking sector in Bosnia and Herzegovina. Also, review of literature revealed that only a limited number of studies were involved into the research of customer perception of price in service context and its relationship with customer satisfaction and customer loyalty. This study seeks to feel these gaps in the literature by proposing an integrated model including four widely used constructs in marketing literature service quality, service price, customer satisfaction and customer loyalty - and test the hypothetical links.

Retail banking was chosen as the context for a study due to several reasons. First of all, retail banking is a typical service industry, in which customers frequently become loyal only after some years of doing business with the same bank. Secondly, banking services are contract-based and usually entail a long term relationship between a customer and a bank. Thirdly, there is a reason to believe that the banking industry faces new challenges when the traditionally stable relationships are challenged by deregulation and increased competition. Finally, these constructs have been studied previously, albeit not in the same way as in the current study. The fact that knowledge about those constructs in retail banking does exists makes it possible to build and compare findings of this study to previously findings.

The banking sector of Bosnia and Herzegovina, contrary to the banking sectors in the most transition countries, is specific for many reasons. It falls under transition countries where initial transitional reforms were stopped because of war. After war damage and highly influences through policies set forth by international organizations (e.g. IMF. EBRD, The etc.) reform of banking sector in Bosnia Herzegovina was pursued in order to create a more competitive environment in accordance with the market conditions. Reform in the banking sector has so far produced best results. Commercial banks (almost totally privatized, with predominantly foreign capital) has been seen as one of the pillars for successful development of other sectors in economy. Also, past study (Brkić and Šahinagić, 2003) reported that banking sector is the most market-oriented sector in Bosnia and Herzegovina. Therefore, it is desirable to conduct the study on service quality, service price, customer satisfaction and loyalty in the context of banking sector in Bosnia and Herzegovina.

Even though there are a small number of studies related to service quality, customer satisfaction and customer loyalty in the banking sector of Western Balkan countries (Pepur, 2006, Pisnik Korda and Snoj, 2010) no study has not investigate the effects of individual dimensions of service price on customer satisfaction and loyalty. Moreover, no study questioning dimensional structure of service quality and service price in the context of Bosnia and Herzegovina's retail banking has been encountered. Therefore, this study aims to contribute to the existing literature in this field by testing the dimensional structure of service quality and service price in the context of Bosnia and Herzegovina's retail banking.

The remainder of this paper is organised in five sections. In section two, the proposed model of effects of service quality and service price dimensions on customer satisfaction and loyalty is presented. In section three, the data collection procedure along with measures applied in the current study are described. Results for exploratory factor analysis, regression 
analysis and descriptive analysis are presented in section four. Conclusion and managerial implications are noted, and limitations and future direction are discussed in section five.

\section{CONCEPTUAL MODEL AND HYPOTHESIS DEVELOPMENT}

Based on the literature review and results of preliminary exploratory factor analysis of data collected from the present study, we proposed the conceptual model of effects of service quality and service price dimensions to customer satisfaction and loyalty. The proposed model is shown in Figure 1. Research model includes a group of exogenous variables (those excluded from the model) and a group of endogenous variables (those included in the model). Initially, the endogenous variables were: (1) tangibles (2) reliability; (3) responsiveness; (4) assurance; (5) empathy; (6) price transparency; (7) price reliability; (8) price-quality ratio; (9) relative price; and (10) price fairness. It is pertinent to note here that a preliminary statistical analysis of data collected through an exploratory factor analysis method found no proof of original five dimensions of the service quality or five dimensions of the service price. More specifically, three service quality dimensions were identified: customer orientation (original dimensions therein being: assurance, empathy and responsiveness), reliability and tangibles, as well as three service price dimensions: price transparency, reference price (original dimensions therein being: relative price, price-quality ratio and price fairness) and price reliability. In this model, customer satisfaction and loyalty are observed as exogenous variables, although customer satisfaction is observed as an indirect variable.

Figure 1

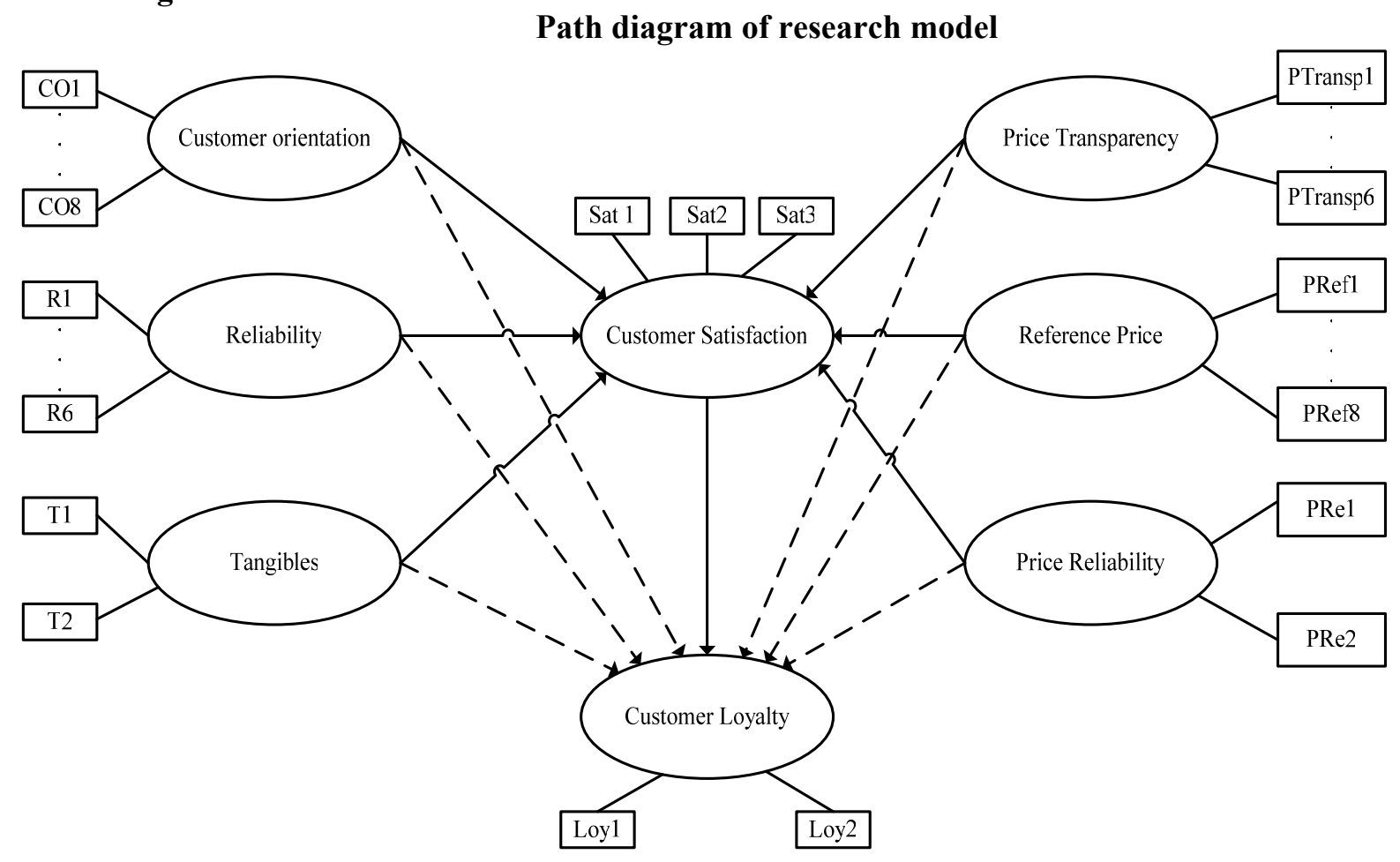

The model (Figure 1) shows relations between individual variables presumed/expected to be of statistical relevance. In order to confirm actual existence of presumed relations between the variables, we have defined the model, examined its statistical reliability and mutual relations and effects. 
In the following section we discuss the theoretical underpinnings for our conceptual framework and outline the hypotheses for our study.

\subsection{Service quality and service price dimensions}

Recognizing the importance of service quality as a source of competitive advantage, researchers advanced the development of models form measuring service quality. It is generally accepted that the concept of quality is abstract and difficult to understand. Thus, it is considered difficult to make this concept concrete and difficult to measure it. However, the most widely used model for measuring service quality is SERVQUAL, a model that was developed by Parasuraman et al. $(1985 ; 1988)$. It relies on the difference between expectation and perception regarding the "consumption" of the service. SERVQUAL model consists of five dimensions: (1) tangibles - physical facilities, equipment and appearance of personnel; (2) reliability - ability to perform the promised service dependably and accurately; (3) responsiveness - willingness to help customers and provide prompt service; (4) assurance knowledge and courtesy of employees and their ability to inspire trust and confidence; and (5) empathy - caring, the individualized attention the firm provides its customers. Although there have been many studies using the SERVQUAL model as a framework in measuring service quality, there have also been theoretical and operational criticisms directed towards this model. One particular area of criticism has been the scale's dimensionality across different service settings and cultural contexts. Although Parasuraman et al. (1998) proposed five "universal" dimensions that were supposed to measure service quality in any industry, the majority of studies that have used the instrument have reported a variety of dimensions (Raajpoot, 2004; Zhou, 2004; Cronin and Taylor, 1992; Babakus and Boller, 1992; Carman, 1990).

Carman (1990), for instance, tested SERVQUAL scale in four service setting and found six to nine dimensions, depending on the industry. It is argued that the variability in the nature of SERVQUAL dimensions is the result of cultural differences across countries or ethnicities. Customer values and beliefs, which change from one culture to another, largely determine the importance and perception of service quality. In this respect, Raajpoot (2004) developed and tested PAKSERV model of service quality to measure service quality in nonWestern (i.e. Pakistan) cultural settings. The PAKSERV findings confirmed SERVQUAL dimensions of tangibles, reliability and assurance, but replaced the responsiveness and empathy with three new dimensions: sincerity, formality and personalization. In a replication study, Cronin and Taylor (1992) reported that the five-dimension structure of SERVQUAL could not be confirmed in any of their samples. They performed empirical test with four alternative service quality models and concluded that the unweighted SERVPERF measure (performance only) performs better than other measure of service quality. In order to define dimensions of service quality in the banking sector of Bosnia and Herzegovina we hypothesize the following:

H1: Service quality can be conceptualized as multidimensional construct.

The central role of price as a purchasing determinant as well as in post-purchasing process is well recognized. In a qualitative study focusing on switching behavior, Keaveney (1995) reported that more than half customers switched because of poor price perception (compared to competitors). Varki and Colgate (2001) arrived at similar results in their study of banking industry. They concluded that price perception directly influences customer satisfaction, the likelihood of switching, and the likelihood of recommendation to others. Most of such studies that examine the price effect to the customer's perception of a product or 
a service have actually looked into single dimension of the price. These authors have usually focused on single dimension of the price, e.g. an effect of price fairness to the price perception (Campbell, 1999; Xia et al., 2004), the price - quality ratio (Fornell et al.1996), or an effect of perceived price to customer satisfaction and behavior (Varki and Colgate, 2001).

The second downside to current literature on the price effect to a purchase decision is a fact that only their lesser part discusses the service sector or banking services in particular. Prompted by the aforesaid, Matzler et al. (2006) have gone through an empirical research of the price effect to the customer satisfaction in the banking sector. Therein, they have found that the price is in fact a multidimensional construct consisting of five dimensions: (1) price transparency - clear, comprehensive, current and effortless overview about a company's quoted prices; (2) price/quality ratio - ratio or trade-off between quality of the service and monetary costs; (3) relative price - price of the offer compared to that of competitors; (4) price reliability - fulfillment of raised price expectations and prevention of negative "price surprises"; and (5) price fairness - customers' perception of whether the difference between the socially accepted price or another comparative party is reasonable, acceptable, or justifiable. In order to assess the dimensional structure of service price in the context of Bosnia and Herzegovina's retail banking, we hypothesize the following:

H2: Service price can be conceptualized as multidimensional construct.

\subsection{Effects of service quality dimensions on customer satisfaction and loyalty}

Customer satisfaction is generally defined as the full meeting of one's expectations (Oliver, 1980) and can be described as the feeling or attitude of a customer towards a product or service after it has been used. Numerous studies from different service sectors have investigated the relationship between service quality and customer satisfaction. Although researchers have agreed that there is a relationship between the two constructs, there has been no consensus regarding the direction of this relationship. Some researchers have proposed a causal link from customer satisfaction to service quality (Bitner et al., 1990), whereas others researchers have proposed a causal link in the opposite direction (Bolton and Drew, 1991). While a substantial amount of research has reported a causal link between service quality and customer satisfaction (e.g. Anderson and Sullivan, 1993; Bolton and Drew, 1991; Cronin and Taylor, 1992), few have investigated the link between each of the service quality dimensions and satisfaction and have reported some mixed results (Johnston, 1995, 1997; Lassar et al., 2000; Zhou, 2004; Arasli et al., 2005). For example, Arasli et al. (2005) reported that assurance, reliability, empathy and tangibles dimensions of service quality were predictors of customer satisfaction in the Cyprus banking sector. Additional support comes from Zhou (2004), who reported that reliability and assurance were important predictors of satisfaction for bank customers in China. Based on this, we hypothesize the following:

H3a: Customer orientation is positively related to customer satisfaction.

$\mathrm{H} 3 \mathrm{~b}$ : Reliability is positively related to customer satisfaction.

$\mathrm{H} 3 \mathrm{c}$ : Tangibles is positively related to customer satisfaction.

H4: Customer orientation, reliability and tangibles have significantly different effect on customer satisfaction.

Past studies have reported that perceived service quality has an impact on customer loyalty. In their study on retail trade, Wong and Sohal (2003) found a positive relationship between service quality and customer loyalty. Other researchers had discovered a positive 
relationship between service quality and loyalty in the banking sector (Bloemer, 1998, Ehigie, 2006). All the researchers have unilaterally agreed that service quality is related to behavioral outcomes, especially in the form of word-of-mouth, recommendation and switching behavior. Based on findings of past studies we hypothesize the following:

H5a: Customer orientation is positively related to customer loyalty.

$\mathrm{H} 5 \mathrm{~b}$ : Reliability is positively related to customer loyalty

H5c: Tangibles is positively related to customer loyalty

H6: Customer orientation, reliability and tangibles have significantly different effect on customer loyalty.

Customer satisfaction is a main determinant of customer loyalty. Numerous studies show the positive relationship between satisfied customers and repurchase intentions (Mittal and Kamakura, 2001; Reichheld and Sasser, 1990; Zeithaml et al., 1996). Positive effects of satisfaction on loyalty are reflected in the customer's intentions to repurchase a product or service and his/her willingness to recommend it other people. As a consequence firms can be assured of a stable customer base, thereby reducing the acquisition and transaction costs, and attenuating the volatility of revenues (Srivastava et al., 1999). From many studies we know however that customer satisfaction does not translate directly into customer loyalty, and that the relationship between satisfaction and loyalty is not a linear one (Oliver, 1999). Despite these contradictory results there is no doubt that customer satisfaction is a precondition for loyalty. Based on this, the following hypothesize is formulated:

H7: Overall customer satisfaction has positive influence on customer loyalty.

\subsection{Effects of service price dimensions on customer satisfaction and loyalty}

Matzler et al. (2006) stated that the customer satisfaction with a certain price should be observed as the multidimensional construct. Also, they found that five dimensions strongly influence overall price satisfaction, word-of mouth and switching intentions. With this respect, customer needs that are linked to a price are quite complex and vary in different stages of the purchase decision process. Still, we should point out that customers do not have formed price expectations toward all these dimensions in every purchase situation. A matter of which price dimensions and to which extent customers have indeed formed their expectations depends primarily on their interest in the price of a product or service they intend to purchase. The customer's price interest is determined by several factors, e.g. factors that influence price sensitivity (Nagle and Holden, 1995) and product or brand involvement. Involvement is indicative of a cognitive effort the consumer invests when ordering a service. As far as customer satisfaction is concerned, low involvement will result in limited information processing with little formal search and evaluation of alternatives (Bennett et.al, 2005; Oliver, 1997). In this case, only few price dimensions will be relevant. However, once customers ascertain high purchase risk, they tend to make complex purchase decisions. Should this happen, their relevance span will encompass more price dimensions.

Matzler et al. (2007) have confirmed in their empirical study that different price dimensions have an asymmetrical effect on the customer satisfaction and that price / quality ratio, price fairness and relative price can be taken for basic factors, while price transparency is a performance factor and price reliability is an excitement factor. They concluded that overall price satisfaction can be increased when satisfaction with performance and excitement factors is enhanced. 
In the line with the findings of previous research, we hypothesize the following:

H8a: Price transparency is positively related to customer satisfaction.

$\mathrm{H} 8 \mathrm{~b}$ : Reference price is positively related to customer satisfaction.

H8c: Price reliability is positively related to customer satisfaction.

H9: Price transparency, reference price and price reliability have significantly different effect on customer satisfaction.

As far as we know, there is no empirical research regarding the direct relationship between individual dimensions of service price and customer loyalty. On the other hand, many studies (Keaveny, 1995, Varki and Colgate, 2001) have showed that price perception has a direct effect on the likelihood of switching and the likelihood of recommendation to others. Therefore, we hypothesize the following:

H10a: Price transparency is positively related to customer loyalty.

H10b: Reference price is positively related to customer loyalty.

H10c: Price reliability is positively related to customer loyalty.

H11: Price transparency, reference price and price reliability have significantly different effect on customer loyalty.

\section{RESEARCH METHODOLOGY}

\subsection{Data collection and sample profile}

The citizens with permanent residence in the area of city Sarajevo, who are over 18 years of age and use financial services of at least one bank, were taken as population for this study. Data was collecting using a random sampling method. The questionnaire was carried out through personal interview in respondent's home. The respondents were asked to focus on the bank they use most often. The survey period was three weeks. The whole procedure of data gathering is performed by specialized agency for market research, PrismResearch BIH.

During the research, 519 households have been contacted. In 176 cases we found no member of a household to have an account open with any of the three target banks, while in 17 cases we managed to locate the account holder, but he denied participation in the survey. It was found that 14 questionnaire were not completed correctly. A total of 300 valid questionnaires were completed. The response rate was therefore 57.80 per cent. The sample size met with the requirements suggested by Hair et al. (1999) that a sample size of 200 may be required to ensure appropriate use of maximum likelihood estimation, to generate valid fit measures and to avoid drawing inaccurate inferences.

The basic findings related to demographic profile of the respondents are presented in Table 1. The sample consisted of a slightly high proportion of female customers (53.3 percent), and a fairly wide spread between age segments. In terms of their level of education, a majority of respondents had a secondary school degree (59.7 percent). 
Table 1

Demographic profile of respondents

\begin{tabular}{|c|c|c|c|}
\hline Factor & Category & Frequency & Percentage \\
\hline \multirow[t]{2}{*}{ Gender } & Male & 140 & 46.7 \\
\hline & Female & 160 & 53.3 \\
\hline \multirow{5}{*}{ Customer's age } & $18-25$ & 56 & 18.7 \\
\hline & $26-35$ & 69 & 23.0 \\
\hline & $36-45$ & 60 & 20.0 \\
\hline & $46-55$ & 68 & 22.7 \\
\hline & Over 56 & 47 & 15.6 \\
\hline \multirow[t]{4}{*}{ Customer's education } & Primary school & 7 & 2.3 \\
\hline & Secondary school & 179 & 59.7 \\
\hline & Faculty & 102 & 37.3 \\
\hline & Master's Degree & 2 & 0.7 \\
\hline \multirow{5}{*}{$\begin{array}{l}\text { Customer's current work } \\
\text { status }\end{array}$} & Employed & 181 & 60.3 \\
\hline & Unemployed & 22 & 7.3 \\
\hline & Retired & 55 & 18.3 \\
\hline & Student & 38 & 12.7 \\
\hline & Housewife & 4 & 1.3 \\
\hline \multirow{4}{*}{$\begin{array}{l}\text { Customer's income } \\
\text { (monthly) }\end{array}$} & Under $€ 300$ & 120 & 40.0 \\
\hline & $€ 301-€ 500$ & 106 & 35.3 \\
\hline & $€ 501-€ 1000$ & 74 & 24.7 \\
\hline & Over $€ 1001$ & 0 & 0.00 \\
\hline \multirow{3}{*}{$\begin{array}{l}\text { Duration of relationship with } \\
\text { main bank }\end{array}$} & Less than 1 year & 63 & 21.0 \\
\hline & $2-5$ years & 171 & 57.0 \\
\hline & More than 5 years & 66 & 22.0 \\
\hline \multirow{5}{*}{$\begin{array}{l}\text { Beside my main bank, I bank } \\
\text { with... }\end{array}$} & 1 bank & 68 & 22.6 \\
\hline & 2 banks & 56 & 18.7 \\
\hline & 3 banks & 60 & 20.0 \\
\hline & 4 banks & 17 & 5.7 \\
\hline & I bank only with my main bank & 99 & 33.0 \\
\hline
\end{tabular}

Source: Author's research

\subsection{Measurement instrument}

In order to access the measurement of exogenous and endogenous variables of the defined model, a questionnaire was developed which focused on four measures: (1) service quality; (2) service price; (3) customer satisfaction and (4) customer loyalty. Each item was measured using five-point Liker scale ranging from "strongly disagree" (1) to "strongly agree"' (5). Therefore, the questionnaire contained four parts (sections).

The first part (Section A) of questionnaire contained 22 perception-only items to measure five dimensions of service quality based on the original SERVQUAL instrument developed by Parasuraman et al. (1988). Items are grouped in five original dimensions: tangibles, reliability, responsiveness, assurance and empathy. In the present study, perceptiononly items (SERVPERF model) were used, although we are aware of all limitations in case we do not measure a level of previous expectations. Actual method and capabilities for conducting this research, as well as the fact this involves a specific service type, have mitigated possible remarks and problems certain critics might have seen regarding this model. 
This is due to the fact that respondents in the research have had prior expectations "considered" when deciding for a particular bank.

The Section B of the questionnaire was consisted of 18 items based on the original questionnaire developed by Matzler et al. (2007). These items were grouped according to the five original dimensions of the service price: price transparency, price reliability, price quality ratio, relative price and price fairness.

The overall customer satisfaction was measured using a three items that identified how satisfied a customer felt with regard to the participating banking service provider. The following items have been used: (1) "I am very satisfied with the Bank X", (2) "Bank X comes up to my expectations of a good bank", and (3) "I consider that Bank X is an ideal choice for my banking". In order to measure loyalty, we used a three - items scale based on the work of Beatty and Kahle (1988), Oliver (1997) and Yoo et al. (2000). The following three items regarding the customer loyalty have been used: (1) "I consider myself to be loyal to Bank X", (2) "Bank X would be my first choice for my banking" and (3) "I think I am committed to Bank X". These six items related to customer satisfaction and customer loyalty were presented in the third part of the questionnaire (Section $\mathrm{C}$ ).

The fourth part (Section D) of the questionnaire includes demographic questions (gender, age, qualifications, current work status, average monthly income) and two items one regarding the duration of the customer's relationship with a bank and the other regarding the number of banks the customer banked besides its first (main) bank of choice.

\subsection{Method of data analysis}

The observed data were analyzed using numerous statistical methods and techniques. In general terms, the entire procedure of data analysis took place in three stages: assessment of metric characteristics of applied measure scales, preparation and verification of data for performing the regression analysis and performing the regression analysis. During the first stage of data analysis, the Cronbach alpha model and the exploratory factor analysis were applied. The second stage of the data analysis included a series of analytical procedures to ensure that gathered empirical data meet conditions and prerequisites for performing the regression analysis. More specifically, the following factors could adversely affect validity of the results: (1) distribution of individual variables that deviates from the normal distribution; (2) variables display a bivariate or multivariate multicollinearity; (3) existence of heteroscedasticity among variables (Kline. 1998). The whole procedure of data analysis was performed using statistical package for social sciences (SPSS 12.0). It is important to mention that instead of regression analysis we could have employed a more rigorous method of analysis, such as structural equation modeling (SEM), for testing both, direct and indirect effects between the variables of defined model. Since the purpose of this study is to test only direct effects, regression analysis is employed. 


\section{ANALYSIS AND RESULTS}

This section provides results of analysis on the described variables. This will be followed by Cronbach's alpha model in testing the reliability of the measurement scales, factor analysis and regression analysis.

\subsection{Reliability and factor analysis}

Among the numbers models suitable for determining the reliability of measurement scales, Cronbach's alpha model was selected. It is based upon determining the internal consistency among characteristics (items) which make construction of the selected instrument for service quality measurement. Measurement of internal consistency of characteristics (items), i.e. average correlation coefficients among characteristics (items) was estimated for each dimension of the service quality as well as for the whole measurement instrument. Also, the effect of individual characteristics (items) on the internal consistency of each dimension of service quality was estimated. The characteristics (items) that can lower internal consistency of appertaining dimension were eliminated from further analysis.

Having determined reliability of measurement scales for individual service quality dimensions, we have approached an assessment of convergent and discriminant validity of applied measurement scales. Regarding the pre-analysis testing for suitability of entire sample for factor analysis, Kaiser-Meyer-Olkin measure of sampling adequacy (KMO) was 0.930 and the Bartlett's test of sphericity ( 3930.380) was significant at $\mathrm{p}<0.01$, thus, indicating that the sample was suitable for factor analytic procedures. The exploratory factor analysis using principal component analysis with varimax rotation was employed to assess construct validity.

Table 2

Results of factor analysis (service quality)

\begin{tabular}{llr}
\hline Component & \multicolumn{1}{c}{ Initial variables } & Loading \\
\hline Customer orientation $^{\mathbf{a}}, \boldsymbol{\alpha}=\mathbf{0 . 9 3 8}$ & 21. Customer's best interest are at hart & 0.840 \\
& 22. Employees understand the specific needs of & 0.809 \\
& customers & \\
& 15. Customers feel safe in their transactions & 0.780 \\
& 14. Employee behavior instills customer confidence & 0.757 \\
& 20. Employees give customers personal attention & 0.731 \\
& 12. Employees are always willing to help & 0.699 \\
& 18. Employees give customers individual attentions & 0.667 \\
& 17. Employees have knowledge to answer questions & 0.636 \\
\hline Reliability $^{\mathbf{b}}, \boldsymbol{\alpha}=\mathbf{0 . 9 0 5}$ & 8. Employees provide their services as promised & 0.817 \\
& 9. Employees insist on error-free records & 0.789 \\
& 7. Employees perform the service right the first & 0.786 \\
& time & 0.644 \\
& 6. Employees show sincere interest in solving & \\
& customer problems & 0.574 \\
& 5. Employees keep promises & 0.525 \\
\hline 10. Employees inform exactly when services will & be performed & 0.885 \\
& 2. Visually appealing physical facilities & 0.828 \\
\hline Tangibles $^{\mathbf{c}}, \boldsymbol{\alpha}=\mathbf{0 . 8 3 5}$ & 1. Modern - looking equipment & \\
& &
\end{tabular}

Note: ${ }^{a}$ variance explained $=33.821$ percent; ${ }^{b}$ variance explained $=26.366$ percent; ${ }^{c}$ variance explained $=12.656$ percent

Author's calculations 
Using the Kaiser-Guttman rule, we were able to single out three factors (dimensions), i.e. to retain those factors with eigenvalues greater than 1.0 and factor loadings equal to or greater than 0.50 . The exploratory factor analysis pointed out to the fact that certain items are indicative of high factor loadings across several factors (dimensions). The items with the loadings factor greater than 0.50 related to several factors (dimensions), i.e. that had overlaps among two factors, have been eliminated from further research. The items we eliminated belonged to the original dimension of tangibles: "Bank's reception desk employees are neat appearing" (T3) and dimension of responsiveness: "Employees in bank give you prompt service" ( $\operatorname{Re} 2)$ and "Employees in bank are never too busy to respond to your request" $(\operatorname{Re} 4)$. Table 2 herein displays the resulting factor structure of the Varimax rotations. Sixteen items, loading under three dimensions, were extracted from the analysis and these items explained 72.643 percent of the overall variance. Also, we have tested reliability of sub-scales of measure for every identified factor (dimension) by applying the Cronbach alpha coefficient. The overall Cronbach alpha coefficient for the modified SERVQUAL instrument (16 items) is 0.950, while for factors 1 , factor 2 and factor 3 this coefficient equals $0.938,0.905$ and 0.835 respectively.

While the three original dimensions of the service quality - responsiveness, assurance and empathy, do not appear in this research, the model was complemented with another, new dimension - customer orientation. The dimension's name is a result of the author's personal view, pursuant to the idea that the sets of interrelated variables included in the factor can be used to measure "customer orientation" of the bank. More specifically, all items within the dimension "customer orientation" describe the way in which the employees treat the customer at the time of service delivery. Therein, the focus is on paying individual attention to the customer, meeting specific needs of the customer, expressing interest in providing assistance to the customer and solving any potential problem the customer may be having. Out of five statements of the "reliability" dimension, one belongs to the original dimension of "responsiveness". Eight statements of the "customer orientation" dimension have originally belonged to the dimensions "responsiveness", "assurance" and "empathy". All items of the dimension of "tangibles" are the same as the original items. Therefore, hypothesis H1: Service quality can be conceptualized as multidimensional construct, is confirmed.

Results of the factor analysis used to test the multidimensional construct of the service price are presents in the Table 3. 
Table 3

Results of factor analysis (service price)

\begin{tabular}{|c|c|c|}
\hline Component & Initial variables & Loading \\
\hline \multirow[t]{6}{*}{ Price Transparency $^{\mathrm{a}}, \alpha=0.910$} & $\begin{array}{l}\text { 7. Price information is understandable and } \\
\text { comprehensible }\end{array}$ & 0.880 \\
\hline & 6. Price information is complete, correct, and frank & 0.817 \\
\hline & $\begin{array}{l}\text { 5. All price components are clear, comprehensible } \\
\text { and understandable }\end{array}$ & 0.863 \\
\hline & 8. I am properly informed about the prices of services & 0.795 \\
\hline & 3. There is no "hidden" costs & 0.615 \\
\hline & 4. Prices and conditions do not change unexpectedly & 0.571 \\
\hline \multirow[t]{8}{*}{ Price Reference $^{\mathrm{b}}, \alpha=0.920$} & $\begin{array}{l}\text { 11. Terms and conditions of my bank are better than } \\
\text { those of other banks }\end{array}$ & 0.848 \\
\hline & 13. Price and quality meet my needs & 0.817 \\
\hline & $\begin{array}{l}\text { 10. I do not believe that another bank would have the } \\
\text { same or better offer }\end{array}$ & 0.788 \\
\hline & 12. I am convinced that my bank is the best choice & 0.775 \\
\hline & 14. I get a good price-quality ratio & 0.742 \\
\hline & 16. The prices I pay are fair & 0.677 \\
\hline & 17. My bank does not take advantage of me & 0.596 \\
\hline & $\begin{array}{l}\text { 18. Overdrafts do not cause abnormally high interest } \\
\text { rates }\end{array}$ & 0.595 \\
\hline \multirow[t]{2}{*}{ Price Reliability ${ }^{\mathrm{c},} \alpha=0.932$} & 1. Price changes are communicated properly & 0.916 \\
\hline & 2. Price changes are communicated timely & 0,915 \\
\hline
\end{tabular}

Note: ${ }^{a}$ variance explained $=29.941$ percent; ${ }^{b}$ variance explained $=29.835$ percent; ${ }^{c}$ variance explained $=12.780$ percent

Authors' calculations

The pre-analysis testing for suitability of entire sample for factor analysis, KaiserMeyer- Olkin measure of sampling adequacy was 0.915 and the Bartlett's test of sphericity (3967.537) was significant at $\mathrm{p}<0.01$, thus, indicating that the sample was suitable for factor analytic procedures An initial solution to the Varimax rotation resulted in three factors (dimensions), whereas we have remained the factors with eigenvalues greater than 1.0 and factor loadings equal to or greater than 0.50 . There were sixteen statements included in the three factors (dimensions) that explain the $72.555 \%$ of total variance. In order to ascertain reliability of the internal consistency of applied scales of measure, we have calculated the Cronbach alpha coefficient for every factor (dimension). The overall Cronbach alpha coefficient is 0.940 , while their respective values for individual factors are $0.910,0.920$ and 0.932 .

The three original dimensions of the service price - relative price, price / quality ratio and price fairness, do not appear in the research. Items belonging to these service price dimensions have displayed high factor loadings related to the second factor (dimension) marked as "price reference". There are eight items in the "price reference" dimension and they originally belong to dimensions "relative price", "price-quality ratio" and "price fairness". These dimensions relate to a comparison with prices charged by other service companies (banks) for the same service or with a price the customer finds acceptable. In both cases, there was certain point of reference that the customer applied to assess a price of service being offered by a service provider (bank). Since any price used by the customer in this comparison is called the "reference price", we find the dimension's title "reference price" the most suitable for manifest variables (items) included in this dimension. Out of six statements of the "price transparency" dimension, two belong to the original dimension of 
"price reliability". There are two statements, originally belonging to the "price reliability" dimension, that have displayed high factor loadings related to the third factor, i.e. dimension that we marked as "price reliability". These results supported the hypothesis H2: Service price can be conceptualized as multidimensional construct.

\subsection{Regression analysis}

In order to examine the univarite normal distribution of individual variables, we have calculated a skewness index and a kurtosis index for every single variable. Results have shown that both indices are within acceptable limits (absolute values are below 3 for the skewness index and below 10 for the kurtosis index), i.e. there is a normal distribution for all variables in the model. Given that it is possible for the high correlation between two variables to imply the bivariate multicollinearity, we have used a correlation matrix for all variables as to determine the multicollinearity among them. Results of the correlation analysis have led to a conclusion that there is no unacceptable level of the bivariate collinearity among the variables as values of all correlation coefficients are below 0.83 . Also, we have looked into a variance inflation factor (VIF) in order to examine the multicollinearity for more than two variables, i.e. in case when three or more variables have high correlation coefficient. The findings of the VIF test (Table 4) show that all observed variables are within the acceptable limits. The VIF test has helped us determine that the collinearity level among analyzed variables is acceptable (the VIF test benchmarks at 10 , so values above this figure are indicative of significant multicollinearity). The homoscedasticity of individual variable pairs, wherein the defined model presumed to be in a direct causal relationship, were subject to the Levene's test of homogenity of variances. This test has proven to be insignificant $(p>0.05)$ related to all examined variable pairs, hence this makes us conclude that the hypothesis of homoscedasticity of certain relations cannot be dismissed, meaning that the relation between tested variables is homoscedastic.

Table 4

\begin{tabular}{llcc}
\multicolumn{2}{c}{ Results of VIF test } & \multicolumn{2}{c}{ Collinearity Statistics } \\
\hline Model & Variables & Tolerance & VIF \\
\hline Satisfaction & Customer orientation & 0.272 & 3.674 \\
& Reliability & 0.286 & 3.502 \\
& Tangibles & 0,498 & 2.008 \\
& Price Transparency & 0.272 & 3.679 \\
& Reference Price & 0.285 & 3.507 \\
& Price Reliability & 0.384 & 2.607 \\
\hline Loyalty & Customer orientation & 0.263 & 3.798 \\
& Reliability & 0.268 & 3.810 \\
& Tangibles & 0.489 & 2.044 \\
& Price Transparency & 0.258 & 3.882 \\
& Reference Price & 0.262 & 3.810 \\
& Price Reliability & 0.367 & 2.724 \\
& Satisfaction & 0.188 & 5.323 \\
\hline
\end{tabular}

Author's calculations

As we have ascertained that the collected empirical data meets the primary presumptions for performing regression analysis, we were able to approach the next stage in the process. The summarized results of regression analysis are presented in Table 5. The results of the first model (SAT model) indicate that 81.2 percent $\left(\mathrm{R}^{2}=0.812\right)$ of the variance 
in customer satisfaction can be explained by the dimensions of service quality (customer orientation, reliability, tangibles) and service price (price transparency, reference price, price reliability). Findings from the second model (LOY model) indicate that 79.6 percent $\left(\mathrm{R}^{2}=0.796\right)$ of the variance in customer loyalty can be explained by the dimensions of service quality (customer orientation, reliability, tangibles), service price (price transparency, reference price, price reliability) and customer satisfaction.

Table 5

Results of regression analysis

\begin{tabular}{|c|c|c|c|c|}
\hline Model & $\begin{array}{c}\text { Standardized } \\
\text { coefficients }\end{array}$ & $\begin{array}{c}\begin{array}{c}\text { Standardized } \\
\text { error }\end{array} \\
\end{array}$ & t-value & p-value \\
\hline Satisfaction- SAT $\left(\mathrm{R}^{2}\right)$ & $(0.812)$ & & & \\
\hline Customer orientation & 0.153 & 0.050 & 3.142 & 0.002 \\
\hline Reliability & 0.205 & 0.048 & 4.324 & 0.000 \\
\hline Tangibles & 0.082 & 0.038 & 2.297 & 0.001 \\
\hline Price Transparency & 0.195 & 0.049 & 4.022 & 0.000 \\
\hline Reference Price & 0.238 & 0.050 & 5.028 & 0.000 \\
\hline Price Reliability & 0.149 & 0.038 & 3.637 & 0.000 \\
\hline Loyalty - LOY $\left(\mathbf{R}^{2}\right)$ & $(0.796)$ & & & \\
\hline Customer orientation & 0.136 & 0.051 & 2.638 & 0.009 \\
\hline Reliability & 0.148 & 0.050 & 2.910 & 0.004 \\
\hline Tangibles & 0.100 & 0.039 & 2.641 & 0.009 \\
\hline Price Transparency & 0.140 & 0.050 & 2.694 & 0.007 \\
\hline Reference Price & 0.170 & 0.052 & 3.398 & 0.001 \\
\hline Price Reliability & 0.113 & 0.039 & 2.910 & 0.004 \\
\hline Satisfaction & 0.201 & 0.058 & 3.289 & 0.001 \\
\hline F test (Satisfaction) & 211.124 & $\mathrm{df}=6$ & & 0.000 \\
\hline F test (Loyalty) & 162.806 & $\mathrm{df}=7$ & & 0.000 \\
\hline
\end{tabular}

Author's calculations

The positive value of the standardized coefficient made us conclude there is a positive relation between independent and dependant variable, while the negative value is indicative of a negative relation between the independent and dependant variable. The standardized coefficient's value also points out to an extent to which every independent variable affects the dependant variable. This is rooted on a presumption that all other independent variables remain unchanged (constant). Every standardized coefficient has an associated and standardized error pointing out to the degree to which values of standardized coefficients would vary across different samples. The statistical relevance of regression coefficients is established on basis of t-statistics and accompanying p-values.

Standardized coefficients used to assess direct causal relations between latent variables were specified in the defined model and presented in the Table 6. Results of the regression analysis revealed the statistically significant positive relation between customer satisfaction and customer loyalty $(\beta=0.201)$. This has also confirmed the hypothesis H7: Overall customer satisfaction has positive influence on customer loyalty 
Table 6

Standardized coefficients estimates $(n=300)$

\begin{tabular}{llccc}
\hline & \multicolumn{1}{c}{ Hypothesis } & $\begin{array}{c}\text { Standardized } \\
\text { coefficients }\end{array}$ & t-value & p-value \\
\hline H3a & Customer orientation $\rightarrow$ Satisfaction $(+)$ & 0.153 & 3.142 & 0.002 \\
H3b & Reliability $\rightarrow$ Satisfaction $(+)$ & 0.205 & 4.324 & 0.000 \\
H3c & Tangibles $\rightarrow$ Satisfaction $(+)$ & 0.082 & 2.297 & 0.001 \\
\hline H8a & Price Transparency $\rightarrow$ Satisfaction $(+)$ & 0.195 & 4.022 & 0.000 \\
H8b & Reference Price $\rightarrow$ Satisfaction $(+)$ & 0.238 & 5.028 & 0.000 \\
H8c & Price Reliability $\rightarrow$ Satisfaction $(+)$ & 0.149 & 3.637 & 0.000 \\
\hline H7 & Satisfaction $\rightarrow$ Loyalty $(+)$ & 0.201 & 3.289 & 0.001 \\
\hline H5a & Customer orientation $\rightarrow$ Loyalty $(+)$ & 0.136 & 2.638 & 0.009 \\
H5b & Reliability $\rightarrow$ Loyalty $(+)$ & 0.148 & 2.910 & 0.004 \\
H5c & Tangibles $\rightarrow$ Loyalty $(+)$ & 0.100 & 2.641 & 0.009 \\
\hline H10a & Price Transparency $\rightarrow$ Loyalty $(+)$ & 0.140 & 2.694 & 0.007 \\
H10b & Reference Price $\rightarrow$ Loyalty $(+)$ & 0.170 & 3.298 & 0.001 \\
H10c & Price Reliability $\rightarrow$ Loyalty $(+)$ & 0.113 & 2.910 & 0.001 \\
\hline
\end{tabular}

Author's calculations

We have established the direct positive links between: reliability and satisfaction $(\beta=$ $0.205)$, customer orientation and satisfaction $(\beta=0.153)$ and tangibles and satisfaction $(\beta$ $=0.082$ ). This leads to a conclusion that all dimensions of the service quality, as determined by the factor analysis, possess statistical relevance in determining the customer satisfaction. Therefore, the set of hypotheses H3a, H3b, H3c is supported. Results of the regression analysis (LOY model) confirmed positive statistically significant relations among: reliability and loyalty $(\beta=0.148)$, customer orientation and loyalty $(\beta=0.136)$, as well as tangibles and loyalty $(\beta=0.100)$. Based on these findings, the set of hypotheses H5a, H5b, H5c is supported. Also, results indicate direct links between price reference and customer satisfaction $(\beta=0.238)$, price transparency and satisfaction $(\beta=0.195)$ and price reliability and satisfaction $(\beta=0.149)$. These results confirm the hypotheses H8a, H8b and H8c. The positive statistically significant relations among price reference and loyalty $(\beta=0.170)$, price transparency and loyalty $(\beta=0.140)$ and price reliability and loyalty $(\beta=0.113)$ are also reported in this study. These results affirmed the set of hypotheses H10a, H10b and H10c.

T-statistics and accompanying p-values have been used to test hypotheses $\mathrm{H} 4$ and H6, i.e. to estimate the effects of the individual dimensions of service quality on customer satisfaction and loyalty. Findings indicate that the strongest predictor of customer satisfaction is reliability, followed by customer satisfaction and tangibles. Also, we have found that the customer loyalty is largely determined by the reliability, followed by customer orientation and tangibles. However, the effect of these dimensions to the customer loyalty is lesser than to the customer satisfaction. These results lead to the conclusion stated under the hypothesis H4: Individual dimensions of service quality have significantly different effect on the customer satisfaction, and hypothesis H6: Individual dimensions of service quality have significantly different effect on the customer loyalty.

The same method has been applied to test hypotheses H9 and H11, i.e. to estimate the effects of individual service price dimensions on customer satisfaction and loyalty. Our conclusion therein was that the price reference is the strongest predictor of customer satisfaction, followed by price transparency and price reliability. Also, we concluded that the price reference contributes the most to the customer loyalty. These results enabled us to confirm hypotheses H9: Individual dimensions of service price have significantly different 
effect on the customer satisfaction and H11: Individual dimensions of service price have significantly different effect on the customer loyalty.

\subsection{Discussion and implications}

Although SERVQUAL is accepted as the universal instrument in measuring service quality, some critics have risen regarding its dimensionality. In the present study SERVQUAL has been reduced to three dimensions: customer orientation, reliability, and tangibles. This finding is in the line with previous studies suggesting that SERVQUAL model needs some adaptation when it has to be implemented in a particular country or industry. As regard the service price, compared to the findings of original study conducted in Austria (Matzler et al., 2006, 2007), the results of the present study reported different dimensional structure of service price. This finding indicates that price satisfaction scale developed by Matzler et al. $(2006,2007)$ need to be adopted to reflect the particular settings of research. In the case of Bosnia and Herzegovina these particularities can be imposed by the specific cultural values of the society, but also by the stage of banking sector's development.

As hypothesized, we find that customer orientation, reliability and tangibles are positively related to customer satisfaction and loyalty. Therefore, it seems reasonable to conclude that customer satisfaction and loyalty can be enhanced by focusing on these dimensions of service quality within the Bosnia and Herzegovina's retail banking. We found that reliability of service is the most important predictor of customer satisfaction and loyalty, which is in the line with prior research (Arasli et al., 2005; Zhou, 2004). Moreover, we found that tangible dimension is positively related to customer satisfaction and loyalty, although the standardized coefficient was smallest in comparison with reliability and customer orientation. This finding is consistent with previous research, by suggesting that physical environment is the important part of the service offering. However, it is not in the line with the extant banking literature, which has been reported that tangible dimension is the most significant predictor of customer loyalty (Wong and Sohal, 2003). Moreover, our findings confirm the mediating role of satisfaction on the relationship among service quality dimensions and customer loyalty and therefore reconfirm the significance of customer satisfaction in the service setting.

Furthermore, it is interesting to note that relative importance of price dimensions in creating customer satisfaction differs between the present study and study conducted in Austria. Whereas the price reliability is the most important price dimension in the sample of retail bank customers in Austria (Matzler et al., 2007), the present study showed that reference price is a major predictor of customer satisfaction and loyalty for bank customers in Bosnia and Herzegovina.

Our findings suggest that bank managers in Bosnia and Herzegovina should focus on customer orientation, reliability and tangible dimensions of service quality with a purpose of measuring, monitoring, and improving the satisfaction and loyalty levels of their customers. Given the significance of reliability of service, bank managers in Bosnia and Herzegovina should provide customers with accurate and prompt service deliveries in order to enhance their satisfaction and loyalty. Regarding the service price, results of present study showed that reference price is the most important predictor of customer satisfaction and loyalty. From a managerial point of view the results suggest that banks should used a more efficiently way of informing customers when they lower interest rates or automatically increase interest rates when interest rates in the market increase, as well as informing them of charging so called "hidden" costs. Also, this means that a bank should focus more on delivering the right quality at the right price (price-quality ratio) and on treating the customers fairly. 


\section{CONCLUSION AND FINDINGS}

The defined model of service price, service quality, customer satisfaction and customer loyalty has proven to be statistically reliable and enabled us to determine the positive and statistically significant relation between the defined variables of the model. Also, the results indicate that individual dimensions of the service quality and service price have different effect on customer satisfaction and customer loyalty. The results of factor analysis confirm that the service quality can be viewed as the multidimensional construct and that the dimensional structure of the service quality in the banking sector of Bosnia and Herzegovina varies from the originally thought. To put it more precisely, a three-factor solution was identified: tangibles, reliability and customer orientation. Also, the dimensionality of the service price construct was confirmed. The empirical data analysis singled out three dimensions of the service price: price transparency, price reliability and reference price. The last dimension - reference price encompasses items already belonging to dimensions of price-quality ratio, relative price and price fairness. The research findings deny universal nature of original SERVQUAL dimensions of the service quality and the service price. An explanation to this can be found in cultural differences and values and beliefs of customers that can vary among countries. This is to say that different cultural values shape the perception of customers that may even result in different dimensions of the service quality and the service price. The research findings show that banks still persist in not paying enough attention to service quality they offer to individual customers.

This study is a first attempt to test the dimensions of the service quality and service price in the context of Bosnia and Herzegovina's retail banking. Besides, it aims to provide an integrated framework for analyzing service quality, service price and customer satisfaction and loyalty. Although it has some limitations, it also opens new research opportunities in service marketing literature, particularly in the area of bank service marketing in the context of the countries in transition.

.However, the present study has several limitations that need to highlight. The sample size was relatively small $(\mathrm{n}=300)$ and the measurement instrument was validated by collecting data from bank customers. Thus, further research should be conducted to confirm the relevance of the findings of this study in different service industries. The applied research methodology can also influence the research results and can hence be considered as the limiting factor. More specifically, the research was based on personal interviews at respondents' homes, thus a limitation here is that no alternative method was employed. A choice of the service quality measuring model can too impose limitations.

Based on described limitations and deficiencies of the research, we have also drawn up certain recommendations for future research studies regarding the concerned topic. Guidelines for any future research of the service quality, service price, customer satisfaction and customer loyalty include: (1) research needs to be conducted over different service sectors (telecommunications, hospitality, education) as to ensure comparison and generalization results of present study; (2) if possible, research needs to cover the entire area of Bosnia and Herzegovina; (3) research needs to examine perceived service quality and service price as observed from a perspective of service company managers; (4) investigate the relations between customer satisfaction and loyalty, on one hand, and service staff satisfaction and loyalty, on the other.

Any future research of the service quality and price, as well as their effect on the customer satisfaction and loyalty, will be largely determined by trends present in the general environment, like: increasing competition among service companies, further advancement of information technologies, level of acceptance of these technologies among general population and changes in behavior of such population (new life styles, new values, etc.). 


\section{REFERENCES}

Anderson, E. W. and Sullivan, M. W. (1993), "The antecedents and consequences of customer satisfaction for firms", Marketing Science, 12(2): 125-143.

Arasli H., Mehtap-Smadi S., and Katircioglu S. T. (2005), "Customer Service Quality in the Greek Cypriot Banking Industry”. Managing Service Quality. 15(1): 41-576.

Babakus, E. and Mangold, G. (1992), "Adapting the SERVQUAL scale to hospital services: an empirical investigation”, Health Services Research, 26(6): 767-85.

Beatty, S.E. and Kahle, R.L. (1988), "Alternative hierarchies of attitudes-behavior relationship: the impact of brand commitment", Journal of Academy of Marketing Science, 16 (2): $1-10$.

Bennett, R., Hartel, C.E.J. and McColl-Kennedy, J.R. (2005), "Experience as a moderator of involvement and satisfaction on brand loyalty in a business-to-business setting", Industrial Marketing Management, 34(1): 97-107.

Bitner, M.J., Booms, B. H. and Tetreault, M. S. (1990), "The service encounter: diagnosing favorable and unfavorable", Journal of Marketing, 54(1): 71-84.

Bloemer, J. (1998), "Investigating drivers of bank loyalty: the complex relationship between image, service quality and satisfaction“, International Journal of Bank Marketing, 16(7): 276-286.

Bolton, N. R. and Drew, H. J. (1991), "A multistage model of customers' assessments of service quality and value", Journal of Consumer Research, 17(4):375-384.

Brkić, N. and Šahinagić, Dž. (2003), "Exploring the market orientation in banking industry: A transitional economy case of Bosnia and Herzegovina", International Conference "From transition to development: globalisation and the political economy and development in transition economies", Sarajevo, October 10-13, Proceeding, pp. 705-717.

Campbell, C. M. (1999), "Perceptions of price unfairness: antecedents and consequences", Journal of Marketing Research, 3(2): 187-199.

Carman, J.M. (1990), “Consumer perceptions of service quality: an assessment of the SERVQUAL dimensions", Journal of Retailing, 66 (1): 33-55.

Cui, C.C., Lewis, B.R. and Park, W. (2003), "Service quality measurement in the banking sector in South Korea", International Journal of Bank Marketing, 21 (4/5)191-201.

Ehigie, B. O. (2006), "Correlates of customer loyalty to their bank: a case study in Nigeria“, International Journal of Bank Marketing, 24(7): 494-508.

Fornell, C., Johnson, D. M., Anderson, W. E., Cha, J. amd Everitt B. B. (1996), "The American customer satisfaction index: nature, purpose and findings", Journal of Marketing 60(4): 7-18.

Hair, J.F., Anderson, R.E., Tatham, R.L. and Black, W.C. (1999), Multivariate Analysis, Prentice-Hall, New York, NY.

Johnston. R. (1995), “The determinants of service quality: satisfiers and dissatisfiers", International Journal of Service Industry Management, 18(5): 53-71.

Johnston, R. (1997), "Identifying the critical determinants of service quality in retail banking: importance and effect", International Journal of Bank Marketing, 15(4): 111-116.

Keaveney, M. S. (1995), "Customer switching behavior in service industries: an exploratory study", Journal of Marketing, 59 (2): 71-82.

Kline, R. B. (1998), Principles and Practice of Structural Equation Modeling, The Guilford Press, New York, NY.

Lassar, W. M., Manolis, C. and Winsor, R. D. (2000), "Service quality perspectives and satisfaction in private banking", International Journal of Bank Marketing, 18(4): 181199. 
Matzler, K., Würtel, A. and Renzl, B. (2006), "Dimensions of price satisfaction: a study in retail banking industry", International Journal of Bank Marketing, 24(4): 216-23.

Matzler, K., Renzl, B. and Faullant, R. (2007), "Dimensions of price satisfaction: a replication and extension", International Journal of Bank Marketing, 25(6): 394-405.

Mittal B. and Lassar M.W. (1998), "Why customers switch? The dynamics of satisfaction versus loyalty", Journal of Services Marketing, 12(3): 177-194.

Mittal, V., and Kamakura; W. A. (2001) "Satisfaction and repurchase behavior: The moderating influence of customer and market characteristics," Journal of Marketing Research 38 (1):

131-42.

Nagle, T. T. and Holden, K. R. (2002), The Strategy and Tactics of Pricing, 3th ed., Pearson Education, Upper Sadlle River, New Jersey.

Oliver, R.L. (1980), "A cognitive model of the antecedents and consequences of satisfaction judgments", Journal of Marketing Research, 17(4): 460-469.

Oliver, R. L. (1997), Customer Satisfaction. A Behavioral Perspective on the Consumer, McGraw-Hill, New York, NY.

Oliver, R. L. (1999), “Whence consumer loyalty?”, Journal of Marketing, 63(special issue): $33-44$.

Parasuraman, A., Zeithaml, V. and Berry, L.L. (1985), "A conceptual model of service quality and its implications for future research", Journal of Marketing, 49(4): 41-50.

Parasuraman, A., Zeithaml, V.A. and Berry, L.L. (1988), "SERVQUAL: a multipleitem scale for measuring consumer perceptions of service quality", Journal of Retailing, 64(1): 12-40.

Pepur, M. (2006), "Service quality in banking sector: concept and measurement", Market, 18(1/2): 53-66.

Pisnik Korda, A. and Snoj, B. (2010), "Development, validity and reliability of perceived service quality in retail banking and its relationship with perceived value and customer satisfaction, Managing Global Transition, 8(2): 187-205.

Raajpoot, N. (2004), "Reconceptualizing service encounter quality in non-western context", Journal of Service Research, 7 (2): 181-201.

Reichheld, F. F. and Sasser, W. E. Jr (1990), "Zero defections comes to services", Harvard Business Review, 68(5): 105-111.

Srivastava, R. K., Shervani, T. A., \& Fahey, L. (1999), "Marketing, business processes and shareholder value: an organizationally embedded view of marketing activities“, Journal of Marketing, 63(special issue): 168-179

Taylor, S. A. and Baker, T. L. (1994), "An assessment of the relationship between service quality and customer satisfaction in the formation of consumers' purchase intentions", Journal of Retailing, 70(2): 163-78.

Varki, S. and Colgate, M. (2001), "The role of price perceptions in an integrated model of behavioral intentions", Journal of Services Research, 3(2): 232-240.

Xia, L., Monroe, K. B. and Cox, L. J. (2004), "The price is unfair! A conceptual framework of price fairness perceptions", Journal of Marketing, 60(4): 1-15.

Wong, A. and Sohal, A. (2003), "Service quality and customer loyalty perspectives on two levels of retail relationships", Journal of Services Marketing, 17(5): 495-513.

Yoo, B., Donthu, N. and Lee, S. (2000), "An examination of selected marketing mix elements and brand equity", Journal of the Academy of Marketing Science, 28 (2): 195-211.

Zeithaml, V. A. (1988), "Consumer perceptions of price, quality and value: A meansend model and synthesis of evidence", Journal of Marketing, 52 (2): 2-22.

Zillur, R. (2004), "Developing customer oriented service: a case study", Managing Service Quality, 14(5): 426-435. 


\section{INTEGRIRANI MODEL CIJENE, KVALITETA USLUGA, ZADOVOLJSTVA I LOJALNOSTI: EMPIRIJSKO ISTRAŽIVANJE U BANKARSKOM SEKTORU BOSNE I HERCEGOVINE}

Relacija između kvalitete, zadovoljstva i lojalnosti korisnika usluga je predmet interesa istraživača već niz desetljeća. I pored velikog broja publiciranih radova o kvaliteti usluge, uloga ove koncepcije te njezine povezanosti sa drugim ključnim marketing koncepcijama je i dalje nejasna. Ovaj rad pokušava objasniti povezanost između percepcije kvaliteta usluge, percepcije cijene usluge, zadovoljstva $i$ lojalnosti. Predloženi model je definiran na osnovu postojećih teorijskih spoznaja. Pored toga, istraživanje je provedeno s ciljem ispitivanja održivosti dimenzija kvalitete usluge i dimenzija cijene usluge u maloprodajnom bankarstvu Bosne i Hercegovine. Kako bi se testirao definirani model $i$ hipoteze istraživanja, provedeno je empirijsko istraživanje na uzorka 300 korisnika bankarskih usluga. Rezultati istraživanja upućuju na zaključak da model pokazuje prihvatljiv nivo odgovaranja empirijskim podacima. Doprinos ovog rada ogleda se u identificiranju utjecaja pojedinih dimenzija kvaliteta i cijene usluge na zadovoljstvo i lojalnost korisnika. Pristup zasnovan na dimenzijama koji je korišten u ovom radu omogućava menadžerima banaka da identificiraju one dimenzije koje najviše doprinose kreiranju zadovoljstva $i$ lojalnosti klijenata. Provedeno istraživanje ima nekoliko ograničenja koja je potrebno istaknuti. Obzirom da je istraživanje provedeno samo na uzorku korisnika usluga u bankarskom sektoru, te da je uključivalo nekoliko banaka i uzorak od 300 ispitanika smatramo da nije moguće generalizirati dobivene rezultate istraživanja. U cilju generalizacije rezultata neophodno je ponoviti istraživanje $u$ drugim uslužnim sektorima i na većem uzorku ispitanika.

Ključne riječi: kvaliteta usluge, cijena, zadovoljstvo klijenta, lojalnost klijenta, maloprodajno bankarstvo 